\title{
A brief comparison of lava flows from the Deccan Volcanic Province and the Columbia-Oregon Plateau Flood Basalts: Implications for models of flood basalt emplacement
}

\author{
Ninad R Bondre ${ }^{1 *}$, Raymond A Duraiswami ${ }^{2}$ and Gauri Dole 2 \\ ${ }^{1}$ Department of Geology, Miami University, Oxford, Ohio 45056 USA. \\ ${ }^{2}$ Department of Geology, University of Pune, Pune 411 00\%, India. \\ *e-mail: bondren1@muohio.edu
}

\begin{abstract}
The nature and style of emplacement of Continental Flood Basalt (CFB) lava flows has been a matter of great interest as well as considerable controversy in the recent past. However, even a cursory review of published literature reveals that the Columbia River Basalt Group (CRBG) and Hawaiian volcanoes provide most of the data relevant to this topic. It is interesting to note, however, that the CRBG lava flows and their palaeotopographic control is atypical of other CFB provinces in the world. In this paper, we first present a short overview of important studies pertaining to the emplacement of flood basalt flows. We then briefly review the morphology of lava flows from the Deccan Volcanic Province (DVP) and the Columbia-Oregon Plateau flood basalts. The review underscores the existence of significant variations in lava flow morphology between different provinces, and even within the same province. It is quite likely that there were more than one way of emplacing the voluminous and extensive CFB lava flows. We argue that the establishment of general models of emplacement must be based on a comprehensive documentation of lava flow morphology from all CFB provinces.
\end{abstract}

\section{Introduction}

Continental flood basalt (CFB) provinces are arguably the most spectacular examples of volcanic activity on the surface of the earth. They cover vast areas (e.g., $>500,000 \mathrm{~km}^{2}$ for the Deccan) and represent the extrusion of phenomenal volumes of lava. Particularly significant is the fact that in most CFB provinces, the majority of lava flows were probably erupted within a very short time span (c.3 my; Courtillot and Renne 2003). Other views regarding the duration of the Deccan episode do, however, exist e.g., (Pande 2002). Substantial information on the morphology and geochemistry of some flood basalt lavas now exists, and different models have been proposed for their emplacement. In spite of this, several questions remain unanswered. One such question pertains to the periods of time that were involved in emplacing discrete flows/flow fields in CFB provinces. This information is critical for estimating the amount of volatiles released into the atmosphere and the bearing this might have on mass extinctions. Considerable debate revolves around whether these lavas were emplaced rapidly or slowly. As additional details of flow morphology from other $\mathrm{CFB}$ provinces become available, these end member models may need to be revaluated.

In this paper, we first present a short discussion on various models of CFB flow emplacement that have been proposed over the years. We then briefly review the morphology of lava flows from the Deccan Volcanic Province (DVP) and the Columbia-Oregon Plateau flood basalts. Rather than a presentation of exhaustive details, we aim to highlight the general similarities as well as differences in the nature of the erupted lavas, both

Keywords. Continental Flood Basalts; lava flows; morphology; emplacement. 
between as well as within these provinces. Finally, we discuss the implications of this comparative study for models of flood basalt emplacement. We suggest that when proposing emplacement models, the CRBG should not be considered as the only analogue for all CFB provinces.

\section{Models of flood basalt emplacement: An overview}

Two characters of flood basalt flows are especially important for the present discussion-length and volume. CFB flows are essentially long $(>100 \mathrm{~km})$, and high volume $\left(\sim 10 \mathrm{~km}^{3}\right)$ lavas. Individual flow fields (collection of flows produced during the same eruptive episode) may have volumes in excess of $1000 \mathrm{~km}^{3}$. Keszthelyi and Self (1998) provide an exhaustive treatment of the ways in which such flows can form. Of primary importance is the amount of cooling over the long distance of transport. There are two possible scenarios, (a) very high velocities of transport such that effects of cooling are neutralised, or (b) heat retention and minimal cooling via an insulating crust, thus doing away with the requirement of rapid transport. Numerous previous publications (e.g., Thordarson and Self 1998; Reidel 1998) have discussed the various models pertaining to CFB flow emplacement. A good summary is provided by Cashman et al (1998) in the introduction to a special section on long lava flows of the Journal of Geophysical Research. At the cost of repeating some of that, we attempt to provide an overview to the general Indian reader who may not be familiar with the details of each model.

One of the earliest attempts to model the emplacement of flood basalt lava flows is the one by Shaw and Swanson (1970). These authors focused on the Yakima basalt flows from the CRBG, which they described as sheet-like, with planar surfaces and columnar jointing, and with volumes on the order of $100 \mathrm{~km}^{3}$. They attributed importance to the fact that the chilled margins of flows retained evidence for minimal crystallization even at great distances from the proposed vent. Based on their modelling, they came up with a scenario of very rapid and turbulent emplacement of the flows with high eruption rates, on the order of $10^{6} \mathrm{~m}^{3} / \mathrm{s}$. At such rates, flows hundreds of kilometres long would have been emplaced in a matter of days or weeks. It is important to note that flows were assumed to be coherent sheets of lava, 10-100 m thick. Shaw and Swanson (1970) recognised that the presence of compound flows (i.e., flows internally constituted of numerous units/lobes) would lead to a longer duration of emplacement. Walker (1973), in his discussion of lengths of lava flows also argued that high eruption rates were necessary to produce long lava flows.

Reidel and Tolan (1992) discussed the emplacement of the large-volume Tepee Butte Member of the CRBG. Based on the length, volume, morphology, and petrography of individual flows, they also called for relatively rapid emplacement consistent with the model of Shaw and Swanson (1970), although they suggested that slightly longer periods of time (one month) were also possible. Aspects of flow morphology leading to their conclusions include sheet-like geometry, evidence of minimum cooling at great distances from the vent, and limited number of internal flow units. They commented on the fact that although compound, the size and extent of individual flow units are orders of magnitude greater than Hawaiian ones.

The emphasis in the above studies was on invoking rapid transport of lava in order to minimise the effects of cooling. The possibility of an insulating mode of transport was not considered. Such a mode of transport, however, was well characterised for young lava flows, especially in Hawaii. The growth of pahoehoe lava flows by endogenous growth or inflation, and thermally efficient transport through lava tubes had been recognised in key studies by Walker (1991), Chitwood (1994), and Hon et al (1994). Thordarson and Self (1998) studied the morphology and emplacement of the Roza Member of the CRBG in great detail, and proposed that the member was essentially a gigantic compound pahoehoe flow field. Based on their observation of numerous morphological features indicative of inflation, and using insights from the study of Hon and others, they proposed that the Roza Member was emplaced over a decade. The development of thermally insulating crusts over individual sheet-lobes was the key to minimize cooling. They pointed out that although the entire flow field may have been emplaced over a long period of time, the rate of lava transport to the flow front was much more rapid. They postulated that at some stage, stable transport systems such as cylindrical tubes may have developed within the lobes, however, they are difficult to identify since they would not have drained. Self et al (1996) also mentioned that there was a lack of obvious lava tubes in the CRBG, although they cited an example of a potential filled tube in the Roza Member.

Reidel (1998) considered the emplacement of CRBG flows with specific emphasis on the Umatilla, Asotin, and Wilbur Creek Members. He presented detailed geochemical evidence suggesting that the two flows constituting the Umatilla Member (Umatilla and Sillusi) were erupted separately and were mixed to form a single flow in the central Columbia Plateau. Reidel demonstrated that the Umatilla flow traversed a distance of almost 
$200 \mathrm{~km}$ from the vent and was emplaced before the Sillusi composition lava was erupted and mixed with it. Based on these constraints, he concluded that fast, laminar flow led to the emplacement of the Umatilla Member, and that the duration was likely a few weeks to a few months, rather than several years. He suggested that fast, channelized emplacement characterized the main parts of the flow, while distal parts were subject to slower emplacement characterized by endogenous growth. He emphasised the fact that geochemistry provided important insights that flow morphology did not.

Bondre et al (2000; 2004) and Keszthelyi et al (1999) recognised that inflated pahoehoe lava flows are very common in the DVP. While compound pahoehoe flows had been recognised from the province since a long time, the role of inflation in their evolution had not been enunciated. Bondre et al (2004) pointed out some key differences between compound pahoehoe lava flows from the DVP and the CRBG. They discussed the implications of the existence of abundant small lobes and hummocky flows for long-distance lava transfer. A slabby pahoehoe flow was identified by Duraiswami et al (2003), who also commented on its position within the Deccan stratigraphy and its implications.

Anderson et al (1999) studied tumuli and sheet lobes in Hawaii and proposed a model of pulsed inflation involving the injection of numerous closely spaced pulses of lava through a system of preferred pathways. Assuming this model of inflation for the interior of a sheet flow, they demonstrated that CFB flows could not be transported over long distances without invoking unreasonable amounts of pressure. Therefore, Hawaiian lava flows could not be analogues for flows such as those constituting the CRBG. This was contested in a comment by Self et al (2000) and again reaffirmed by Anderson et al (2000) in their reply.

It will be clear to the reader that an overwhelming amount of work on CFB flow emplacement is based on the CRBG, and its comparison with younger lavas. It would be appropriate to say that almost all modelling carried out so far pertains strictly to the CRBG.

\section{A brief look at two flood basalt provinces}

The Columbia-Oregon Plateau flood basalts are generally considered to be a composite of two major eruptive packages - the CRBG on the Columbia Plateau and the various flood basalt sequences on the Oregon Plateau, primarily the Steens Basalts. The Oregon Plateau flood basalts are spatially and morphologically distinct and were quite possibly erupted in a fashion distinct from the CRBG flows. They will hence be considered separately.

\subsection{The Deccan volcanic province}

The morphology of lava flows from the DVP has been reviewed by Bondre et al (2004) in the light of recent developments in physical volcanology. Compound pahoehoe flows very similar in character to Hawaiian flows are abundant in the northwestern and central parts of the province (figure 1a). The dimensions of flow lobes constituting these flows are also comparable to Hawaiian flow lobes, and are usually around $2-10 \mathrm{~m}$ thick. Thicker flow lobes $(>15 \mathrm{~m})$ do exist but are fewer as compared to smaller lobes and toes. Individual flow lobes are characterized by the lack of columnar jointing. Whatever jointing may be present is confined to the central parts (cores) of flow lobes, and tends to be either irregular or blocky. Upper crusts of flow lobes are often sheet jointed. Features such as tumuli, squeeze-ups, delicately preserved ropy structure and hummocky pahoehoe flows are further testimony to the similarity with Hawaiian flows. On the whole, these flows show unambiguous local evidence for endogenous growth (inflation) although the means of long-distance transfer are not yet clear (e.g., tubes/sheets). Reports of the presence of lava tubes/channels have been made in the recent past (e.g., Misra 2002). Many of these features may, however, may have been mistakenly identified as has been pointed out by Duraiswami et al (in press) and Dole et al (2002). It has yet to be determined whether tubes are a widespread feature in the Deccan.

'Simple' flows occur in the southeastern, eastern, and northern parts of the province. These are thick $(10-50 \mathrm{~m})$, extensive flows that appear to be single units without being internally divided into flow lobes. The possibility that in any given section, only part of a flow lobe is visible cannot be discounted. However, in most sections observed so far, these flows do not show any evidence for being subdivided internally into flow lobes. Columnar jointing is fairly common, and sometimes occurs in multiple tiers (figure 1b). Fanning of columns is also seen fairly frequently. The flows are almost always capped by oxidized flow-top breccias. Pipe vesicles and segregations are absent in most simple flows, but some flows do show their presence. Evidence for endogenous growth is ambiguous, and there are distinct morphological and textural differences between the compound pahoehoe and the simple flows. The latter tend to show a much finer texture as compared with the former. Vesicle distribution patterns are also significantly different 

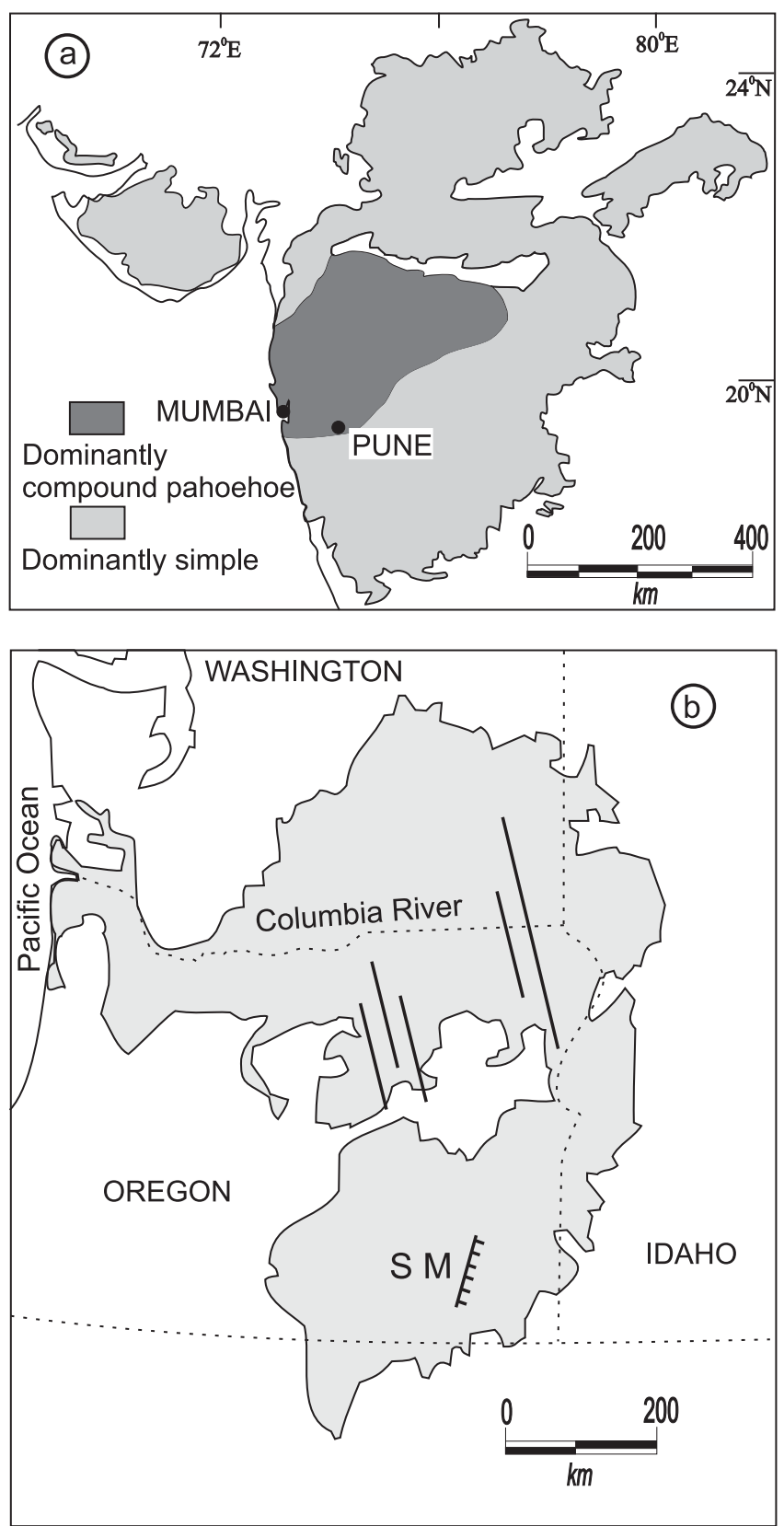

Figure 1. Maps showing the outcrops of the two major flood basalt provinces discussed in the text. (a) Deccan Volcanic Province. (b) Columbia-Oregon Plateau flood basalts. 'SM' refers to Steens Mountain. Dotted lines represent state boundaries, while bold lines indicate the locations of principal feeder dyke swarms.

(Bondre et al 2004). It is possible that the simple flows are essentially rubbly pahoehoe flows (sensu Keszthelyi et al 2003), but this awaits further study.

\subsection{The Columbia River basalt group}

The CRBG is by far the best studied of all flood basalt sequences. Detailed studies on lava flow morphology, geochemistry, and regional correlation of flows and flow sequences have led to the establishment of a robust stratigraphy. In addition to this, excellent geochronological and magnetostraphigraphic control also exists. Thordarson and Self (1998) mention that CRBG flows are characterised by a range of morphology and structures. Long and Wood (1986) subdivided the CRBG flows into three types, primarily based on textures and internal structures. Type 1 flows are relatively thin with basal pipe vesicles, upper vesicular crust, and segregation structures. Type 2 flows are thick $(>50 \mathrm{~m})$ showing multiple tiers of colonnade and entablature (figure 1c). Type 3 flows are also quite thick, but show only 1 tier of colonnade and entablature. Type 2 and 3 flows are often capped by flow-top breccias. According to Long and Wood (1986), flows showing multi-tiered jointing are a significant component of the CRBG stratigraphy. They proposed that such multi-tiered columnar jointing (especially the hackly entablatures with a high proportion of mesostasis) is a result of rapid convective cooling by water ingress. This could potentially have been caused by damming of existing drainage and inundation by water.

Type 1 flows are essentially the same as large sheet lobes recognised by Thordarson and Self (1998) from the Roza Member. Roza flows are constituted of individual flow lobes ranging from 0.4 to $52 \mathrm{~m}$, with an average of $16.7 \mathrm{~m}$. There is a clear predominance of thick sheet lobes, which is clear from table 2 from Thordarson and Self (1998) and one or two thick lobes constitute the entire thickness of the flow in most localities. Many features similar to Hawaiian lava flows such as tumuli and small pahoehoe lobes are observed. Smaller lobes usually fill spaces between the larger ones, and occur at the tops or bases of larger lobes. The lobes show a characteristic internal structure with a relatively thick, vesicular upper crust, vesicle poor core, and a thin vesicular basal crust. Segregation features and a characteristic distribution of vesicles are also observed. While the compound nature of the flow field has been unambiguously demonstrated for the Roza Member, this has not been the case for other members within the CRBG. Descriptions in Reidel (1998) of the Umatilla, Wilbur Creek, and Asotin Members suggest the existence of predominantly single cooling units (flows). Keszthelyi et al (2003) mention that about $20 \%$ of CRBG flows are "rubbly pahoehoe", i.e., flows with rubbly tops but smooth bases. A common theme for many CRBG flows is the profound effect of palaeotopography on their emplacement. Many flows and flow fields present evidence of being channeled by/confined by palaeodrainage of the ancestral Columbia River (see Reidel 1998). 

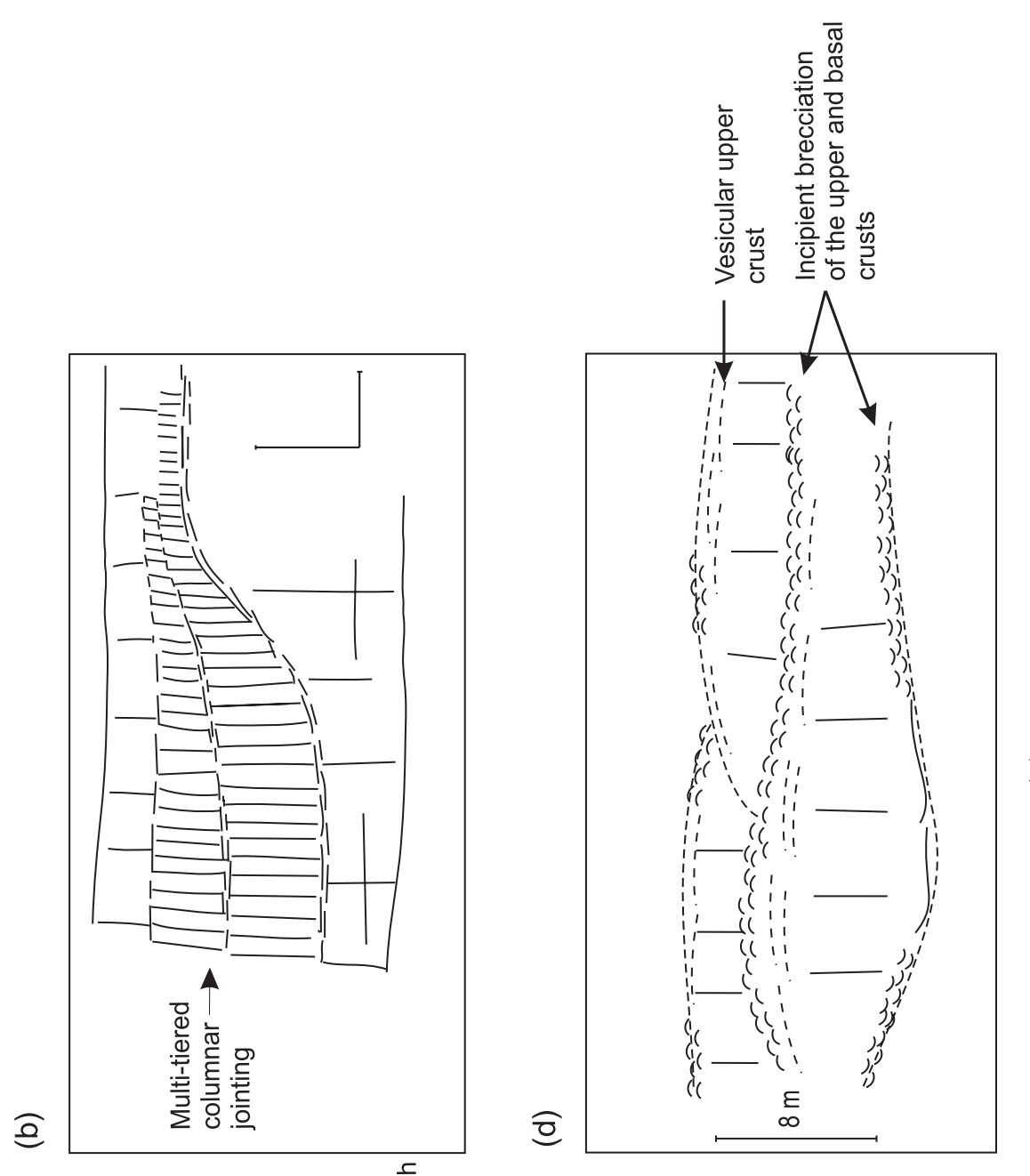

点苛
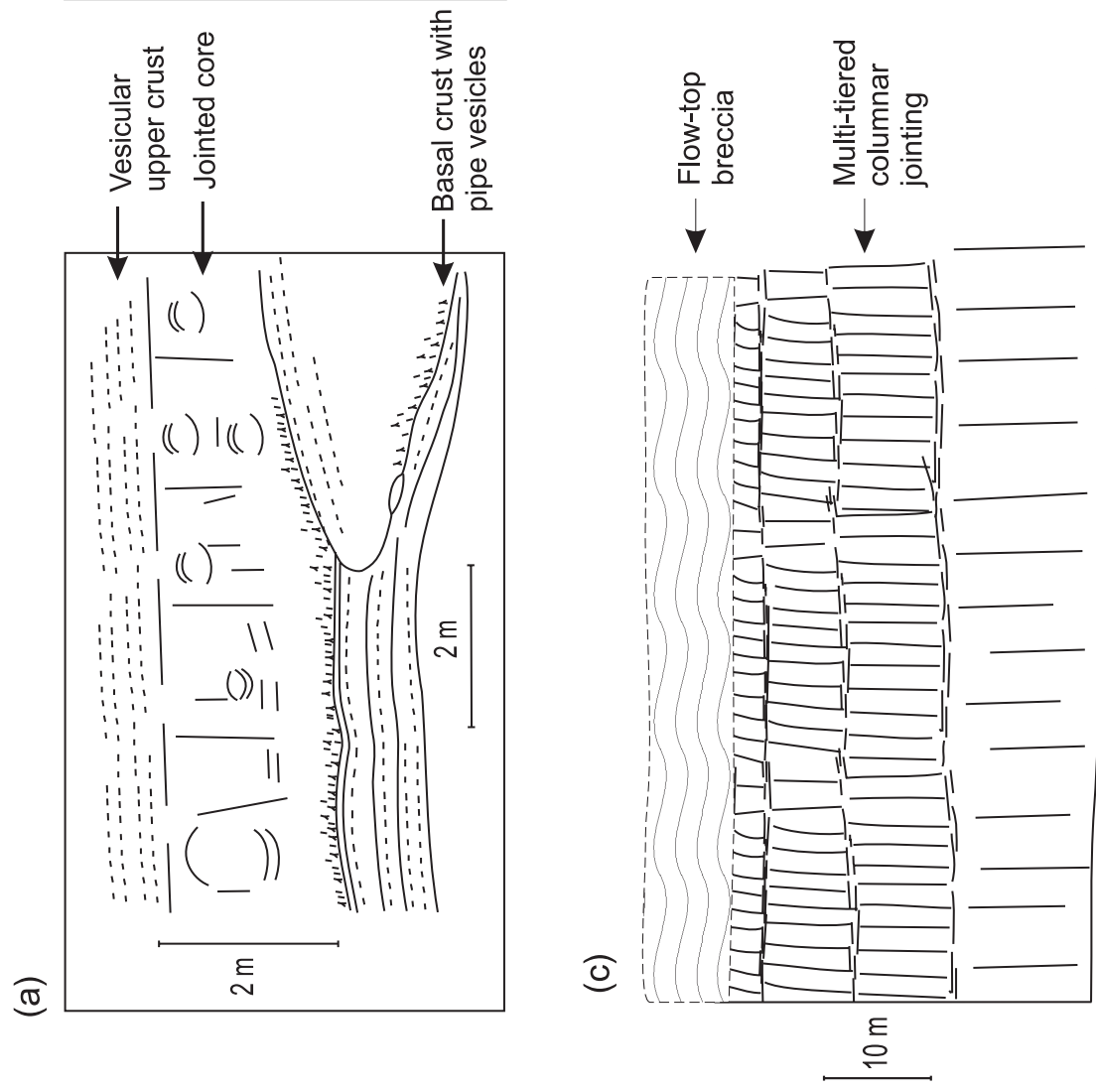

类要

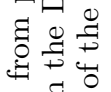

पू

응

은

कै द्व

듬

胥赵

등

i 낭

过

氜

정

ส

50 us

응

웡

임

敢

is

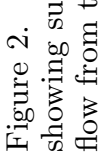




\subsection{The Steens basalts}

Excellent exposures of the Steens basalt succession $(\sim 1 \mathrm{~km})$ with associated feeder dykes can be observed along the Steens mountain fault scarp (figure 1b). This scarp extends for almost $130 \mathrm{~km}$ (e.g., Hart et al 1989) and is related to Basin and Range extension in southeastern Oregon, USA. This has been considered to be the remnant of a shield volcano, the initial diameter of which could have been $80-100 \mathrm{~km}$ (Mankinen et al 1985). Steens basalts along with the nearby basalts of the Malheur Gorge have a volume of almost $60,000 \mathrm{~km}^{3}$ (Carlson and Hart 1988). The area covered by flows emanating from the Steens mountain area may have been over $20,000 \mathrm{~km}^{2}$ (Hart and Carlson 1985). Although the entire section at Steens mountain is considered to have erupted at or around 16.6 Ma (Swisher et al 1990), recent work (Brueseke and Hart 2000) has revealed younger ages of around $15 \mathrm{Ma}$ for some of the nearby sections.

Very little information specifically dealing with the morphology of the Steens lava flows is available in the literature. Our observations and those of others (M E Brueseke and W K Hart, unpublished data) suggest significant morphological differences between the Steens lava flows and those from the other two regions discussed earlier. Here, we describe the nature of flows from a section exposed on the road to the summit of Steens mountain. While many of the flows may be classified as compound, the constituent flow lobes do not appear to be classic pahoehoe as in Hawaii or the Deccan (figure 1d). Their thicknesses (1-12 m) are comparable to the Deccan lobes, but appear to be laterally more extensive, although this may be a manifestation of the nature of exposure and erosion in the province. Most flow lobes display rough or undulating upper and lower surfaces. Upper crusts are vesicular and show varying degrees of brecciation. The central parts (cores) are less vesicular and poorly jointed, while the basal crusts are oxidized, highly vesicular, and either close to brecciation or brecciated. Such features have also been reported by other authors (e.g., Evans and Geisler 2001, figure 23, p. 12). Pipe vesicles are generally absent except in some megaporphyritic flows towards the top of the section. Here, they are associated with vesicle cylinders and segregation veins. The bases of flow lobes sometimes appear to be ribbed or grooved, suggesting that they are somewhat analogous to ropy upper surfaces of pahoehoe flow lobes. It is possible that the emplacement of these flow lobes involved a caterpillar-track type of movement leading to overriding of upper ropy surfaces. Flows with basal breccias are more akin to aa. Extensive flows with multi-tiered columnar jointing typical of the CRBG are not observed.

\section{Discussion}

The brief overview of CFB emplacement models indicates that there seems to be little agreement between the proponents of 'Fast' and 'Slow' models. Interestingly, much of this debate is based on a study of the CRBG flows and their comparison with Hawaiian flows. A recent paper by Anderson et al (1999), the comment on this by Self et al (2000), and the reply by Anderson et al (2000) are illuminating in this respect. Anderson et al (1999) mention that CFB provinces typically display spectacular columnar jointing, which is not the case for inflated lava flows from Hawaii. It appears that the morphology of the CRBG flows (which do show well-developed columnar jointing) has clearly influenced their statement. Self et al (2000) seek to draw a clear distinction between Hawaiian style hummocky flows and CRBG style large sheet flows and lobes, and state that flood basalts dominantly consist of pahoehoe sheet flows. Again, it is clear that this distinction is based on observations of CRBG flows such as the Roza. On the other hand, observations from the DVP suggest that thick and extensive compound pahoehoe flows are internally constituted of hummocky pahoehoe and small lobes, with little to no jointing.

Just a brief review of the morphology of lava flows from the DVP, CRBG, and Steens basalts highlights the existence of variations in flow morphology, even in a single province. We are not the first to point this out and this fact has been recognised in numerous previous studies. To some extent, the morphology seems to be governed by the palaeotopography and drainage (which have considerably influenced many CRBG flows). However, the variations may also have been a result of factors such as different composition and initial volatile contents or varying eruption rates. The possibility that monocentric eruptions dominated some provinces while polycentric eruptions were important in others cannot be ignored. As Jerram (2002) points out, if a single model is not applicable to all provinces, then it cannot be used to determine eruption rates for all types of flows from different provinces. One of the reviewers of this paper, Dr. Steven Anderson made the important point that a single emplacement style for each of these provinces may nevertheless not be ruled out. It is possible that the variations in morphology are a result of different late stage modifications. Flood basalt flows may be emplaced fairly rapidly, as in the model of Reidel (1998) and depending on how abruptly the extrusion rates declines, the final morphology may end up being rubbly/aa, sheet-like, or hummocky pahoehoe. Further documentation is required to test this possibility. 
A critical factor to be considered is whether insights from present day or young volcanic provinces such as Hawaii are directly applicable to ancient, flood basalt flows. Pahoehoe flows in Hawaii are emplaced at low volumetric rates of eruption and flow fields evolve slowly by endogenous growth. Pahoehoe morphology of some CFB flows may hence indicate relatively slow emplacement. However, as Thordarson and Self (1998) have shown, the eruption rates required to emplace the large flows of the Roza Member are still orders of magnitude greater than those for Hawaii. Variations in pahoehoe morphology are observed in $\mathrm{CFB}$ provinces (e.g., rubbly), some of which seem to have few analogues in young or active regions. In such cases, it may be inappropriate to associate them with specific rates of emplacement. Similarly, as Solana et al (2004) have shown, even a typical pahoehoe surface morphology may not necessarily be an indicator of slow emplacement.

The observation that a flow is compound (as most pahoehoe flows are) may not necessarily reflect a low eruption rate. Modelling by Blake and Bruno (2000) suggests that high, but sustained eruption rates can produce a compound flow. They mention that although the compound nature of flows has been assumed to reflect low eruption rates, flood basalts can show compound morphology at least partly because of large volume and not necessarily because of low eruption rates. The striking similarity of compound pahoehoe flows from the DVP with those from Hawaii suggests very similar emplacement styles. However, the absolute sizes of the Deccan flows are orders of magnitude larger than the Hawaiian ones, and in the absence of conclusive evidence about long tube systems, warrant an explanation. Insights derived from the modelling by Blake and Bruno (2000) may prove useful in this respect. One must bear in mind, however, that there may be some inherent limitations in applying laboratory scale experiments to the natural world (Gregg and Keszthelyi 2004).

Thick, extensive flows with rubbly and highly vesicular tops seem to be common to many CFB provinces (e.g., DVP, Faroe Islands, Etendeka). Are these flows essentially rubbly pahoehoe? If so, are rubbly pahoehoe flows emplaced by inflation and is the style of inflation the same as that for typical pahoehoe? If that is the case, the presence of flow-top breccia, differences in internal structure and vesiculation as well as absolute sizes of flow lobes deserve an explanation. It is possible that geochemistry of the lavas plays an important role in determining typical versus rubbly morphology. Compound pahoehoe flows in the DVP as well as in the Etendeka Province (Jerram 2002; Jerram et al 1999) seem to be more magnesian than the simple, rubbly flows, which are of a more evolved charac- ter. The link between geochemistry and flow morphology is well worth investigating.

\section{Conclusions}

It is evident from the above discussion that numerous and even contrasting styles of flow emplacement were likely responsible for the emplacement of CFB lava flows. Observations such as the distinct geographical and stratigraphic disposition of compound pahoehoe flows and simple flows in the DVP suggests that the styles may have varied in space and/or over time even in the same province. The limited available information from some other flood basalts also supports this observation. For example, two distinct morphological types occur in the Faroe Plateau Lava Group (S R Passey, Pers. Comm., 2004) including tubefed pahoehoe and sheet flows with rubbly tops (rubbly pahoehoe?). Similarly, compound pahoehoe flows are overlain by sheet-like, thick flows with rubbly, vesicular tops (rubbly pahoehoe?) in the Etendeka Province (Jerram et al 1999). Such variations within provinces hint at considerably different styles of volcanism during the evolution of a single CFB province. Differences between provinces might be related to the tectonics of individual provinces. Viewing the emplacement of CFB lava flows as fitting into one or the other end-member scenarios may hence not be pragmatic. If this is the case, then it has important implications for emplacement of planetary lava flows and for mass extinctions. The link between CFB provinces and mass extinctions hinges on catastrophic effects of volatile release during individual $\mathrm{CFB}$ eruptions (Courtillot and Renne 2003). Particularly important is the duration of individual eruptions, and the intervals between eruptions (op. cit). A particular model for emplacement of flows can yield specific information about the eruption rates and duration of individual eruptive episodes. It is clear that this is not something that can be generalized for all CFB provinces, but needs to be worked out for every province separately. There is hence an urgent need to document and understand the physical volcanology of all major CFB provinces. Pending such an understanding, models of emplacement designed for the CRBG flows cannot and should not be extrapolated to other CFB provinces, and any generalisation should be viewed with caution.

\section{Acknowledgements}

We would like to thank Matt Brueseke of Miami University for his comments and for sharing unpublished data on aspects of the Steens flows. 
Discussions with Vivek Kale and Shreyas Mangave were very stimulating. We are particularly grateful to Drs. Steven Anderson, Carmen Solana, and Thorvaldur Thordarson for insightful reviews, as well as to Dr. Hetu Sheth for his helpful comments.

\section{References}

Anderson S W, Stofan E R, Smrekar S E, Guest J E and Wood B 1999 Pulsed inflation of pahoehoe lava flows: implications for flood basalt emplacement; Earth. Planet. Sci. Lett. 168 7-18

Anderson S W, Stofan E R, Smrekar S E, Guest J E and Wood B 2000 Reply to: Self et al discussion of 'Pulsed inflation of pahoehoe lava flows: implications for flood basalt emplacement'; Earth. Planet. Sci. Lett. 179 $425-428$

Blake S and Bruno B C 2000 Modelling the emplacement of compound lava flows; Earth Planet. Sci. Lett. 184 $181-197$

Bondre N R, Duraiswami R A, Dole G, Phadnis V M and Kale V S 2000 Inflated pahoehoe lavas from the Sangamner area of the western Deccan Volcanic Province; Current Science $\mathbf{7 8}$ 1004-1007

Bondre N R, Duraiswami R A and Dole G 2004 Morphology and emplacement of flows from the Deccan Volcanic Province, India; Bull. Volcanol. 66 29-45

Brueseke M E and Hart W K 2000 Re-evaluation and new age constraints on the eruptive history of the MidMiocene Steens Basalt, Southeastern Oregon; Geol. Soc. Am. Abstr. Prog. 32 p. 147

Cashman C, Pinkerton H and Stephenson J 1998 Introduction to the special section: Long lava flows; J. Geophys. Res. 103 27281-27289

Carlson R W and Hart W K 1988 Flood basalt volcanism in the Pacific northwestern United States. In: Continental Flood Basalts (ed) J D Macdougall; (Dordecht: Kluwer Acad Pub) 35-62

Chitwood L A 1994 Inflated basaltic lava; examples of processes and landforms from Central and Southeast Oregon; Oregon. Geol. 56 11-20

Courtillot V E and Renne P R 2003 On the ages of flood basalt events; C. R. Geoscience 335 113-140

Dole G, Duraiswami R A and Bondre N R 2002 Discussion on "Arterial system of lava tubes and channels within Deccan Volcanics of western India" by K S Misra; J. Geol. Soc. India 60 597-599

Duraiswami R A, Dole G and Bondre N R The Songir structure: Inflated lava flow or tube? J. Geol. Soc. India (in press)

Duraiswami R A, Dole G and Bondre N R 2003 Slabby pahoehoe from the western Deccan Volcanic Province: evidence for incipient pahoehoe-aa transitions; J. Volcanol. Geotherm. Res. 121 195-217

Evans J G and Geisler T M 2001 Geologic field trip guide to Steens Mountain Loop Road, Harney County, Oregon; Bull. USGS 2183 15pp

Gregg T K P and Keszthelyi L P 2004 The emplacement of pahoehoe toes: Field observations and comparison to laboratory simulations; Bull. Volcanol DOI: 10.1007/s00445-003-0319-5

Hart W K and Carlson R W 1985 Distribution and geochronology of Steens Mountain-type basalts from northwestern Great Basin; Isochron/West 43 5-10

Hart W K, Carlson R W and Mosher S 1989 Petrogenesis of the Pueblo Mountains basalt, southeastern Oregon and northern Nevada; Geol. Soc. Am. Spec. Pap. 239 367-378

Hon K, Kauahikaua J, Denlinger R and Mackay K 1994 Emplacement and inflation of pahoehoe sheet flows: Observations and measurements of active lava flows on Kilauea Volcano, Hawaii; Bull. Geol. Soc. Am. 106 $351-370$

Jerram D A 2002 Volcanology and facies architecture of flood basalts. In: Volcanic Rifted Margins (eds) M A Menzies, S L Klemperer, C J Ebinger, and J Baker, Geol. Soc. Am. Spec. Pap. 362 119-132

Jerram D A, Mountney N, Holzforster F and Stollhofen H 1999 Internal stratigraphic relationships in the Etendeka Group in the Huab Basin, NW Namibia: Understanding the onset of flood volcanism; J. Geodynamics $\mathbf{2 8}$ 393-418

Keszthelyi L and Self S 1998 Some physical requirements for the emplacement of long lava flows; J. Geophys. Res. $10327447-27464$

Keszthelyi L, Self S and Thordarson T 1999 Application of recent studies on the emplacement of basaltic lava flows to the Deccan Traps; In: Deccan Volcanic Province (ed) K V Subbarao. Mem. Geol. Soc. India 43 485-520

Keszthelyi L, Thordarson T and Self S 2003 Quantitative assessment of models for the emplacement of the Columbia River Basalt lava flows; Geol. Soc. Am. Abstr. Prog. 35136

Long P E and Wood B J 1986 Structures, textures and cooling histories of Columbia River Basalt flows; Bull. Geol. Soc. Am. 97 1144-1155

Mankinen E A, Prevot M, Gromme C S and Coe R S 1985 The Steens Mountain (Oregon) geomagnetic polarity transition, 1. Directional history, duration of episodes and rock magnetism; J. Geophys. Res. 90 10393-10416

Misra K S 2002 Arterial system of lava tubes and channels within Deccan volcanics of western India; J. Geol. Soc. India 59 115-124

Pande K 2002 Age and duration of the Deccan Traps, India; a review of radiometric and paleomagnetic constraints; Proc. Indian Acad. Sci. (Earth Planet. Sci.) 111 115-123

Reidel S P 1998 Emplacement of Columbia River flood basalt. J. Geophys. Res. 103 27393-27410

Reidel S P and Tolan T L 1992 Eruption and emplacement of flood basalt: An example from the large-volume Teepee Butte Member, Columbia River Basalt Group; Bull. Geol. Soc. Am. 104 1650-1671

Self S, Thordarson T, Keszthelyi L, et al 1996 A new model for the emplacement of Columbia River basalts as large, inflated pahoehoe lava flow fields; Geophy. Res. Lett. $\mathbf{2 3}$ 2689-2692

Self S, Keszthelyi L, Thordarson T 2000 Discussion of: 'Pulsed inflation of pahoehoe lava flows: Implications for flood basalt emplacement', by Anderson et al Earth. Planet. Sci. Lett. 179 421-423

Shaw H R and Swanson D A 1970 Eruption and flow rates of flood basalts: Proceedings of the Second Columbia River Basalt Symposium, Cheney 271-299, East Washington State College Press

Solana M C, Kilburn C J, Rodriguez Badiola E and Aparicio A 2004 Fast emplacement of extensive pahoehoe flow fields: the case of the 1736 flows from the Montana de la Nueces, Lanzarote; J. Volcanol. Geotherm. Res. 132 189-207

Swisher C C, Ach J A and Hart W K 1990 Laser fusion $40 \mathrm{Ar} / 39 \mathrm{Ar}$ dating of the type Steens Mountain Basalt, southeastern Oregon, and the age of the Steens 
geomagnetic polarity transition; EOS, Trans. Am. Geophy. Union 71 p. 1296

Thordarson T and Self S 1998 The Roza Member, Columbia River Basalt Group: A gigantic pahoehoe lava flow field formed by endogenous processes?; J. Geophys. Res. 103 27411-27445
Walker G P L 1973 Lengths of lava flows; Phil. Trans. R. Soc. London 274 107-118

Walker G P L 1991 Structure, and origin by injection of lava under surface crust, of tumuli, lava rises, lava-rise pits, and lava-inflation clefts in Hawaii; Bull Volcanol 53 546-558 